\title{
THE RESPONSE OF RESIDENCE-BASED SCHEMES IN THE NETHERLANDS TO CROSS-BORDER MOVEMENT
}

\author{
Frans PenNings*
}

\begin{abstract}
The Netherlands already had a residence-based scheme for old-age pensions when the first Coordination Regulation came into force. This national scheme incorporated a prorata system from the start and fits rather well, despite differences in character, with the coordination rules. Health care became organised in a residence-based scheme in 2004, and is based on a contributory system that also fits well with the coordination rules. Special non-contributory benefits and social assistance are more vulnerable to the growth of mobility. Although there are certainly deficiencies and challenges in the system, there are various techniques in residence-based schemes that can be used to control access by mobile persons and at the same time to ensure a minimum income or provision. This makes it interesting to carry out a comparison with other residencebased schemes.
\end{abstract}

Keywords: coordination rules; free movement; minimum income; residence permit; residence-based schemes

\section{INTRODUCTION TO THE RESIDENCE-BASED SCHEMES}

The Dutch social security system is a combination of residence-based insurance schemes and employees' insurance schemes, supplemented by subsistence schemes (public assistance, special non-contributory benefits and provisions).

Residence-based insurance schemes were introduced for risks for which coverage was deemed desirable for everyone living in the country (old-age benefits, survivors' benefits, family benefits, benefits for persons who were disabled before the age of 18 , and health care provisions) - see further, Section 3.1 below. Employees' insurance schemes protect only those working for an employer (and a limited group of

Professor of Labour Law and Social Security Law at Utrecht University, the Netherlands, Guest Professor at Gothenburg University, Sweden and joint editor of EJSS. Address: Achter St. Pieter 200, NL 3512 HT Utrecht, the Netherlands; phone: +31 30253 7258; email: f.pennings@uu.nl. 
assimilated categories, such as, under some conditions, homeworkers) and cover the risks of unemployment, disability and sickness.

The residence-based schemes for old-age benefits, long-term care benefits and survivors' benefits are financed by contributions. Only persons with a very low income do not pay contributions and for them being a resident is sufficient to be insured.

Family benefits and benefits for persons who were already disabled before the age of 18 are paid from taxes. Here there is no connection with contributions. For the former schemes, this way of financing was the result of a decision in the past (employers were to be compensated for the cancellation of another subsidy scheme). For the young disabled the financing method follows from the nature of the risk: those covered have not worked and thus cannot have paid contributions. Health care benefits are based on private schemes, though regulated by legislation. For these schemes contributions have to be paid to private insurance companies.

Public assistance is provided on the basis of the Participatiewet (Participation Act). Article 11 provides that any person of Dutch nationality living in the Netherlands who is in such circumstances or threatens to become in such circumstances that s/he does not have the means for paying the necessary costs of living is entitled to public assistance. Aliens who are legally staying in the Netherlands are assimilated according to specified sections of Article 8 of the Aliens Act, with the exception of the cases mentioned in Article 24(2) of Directive 2004/38. Thus, living in the Netherlands is a necessary but not a sufficient requirement. One must also satisfy the condition on nationality or have a statutorily specified residency status.

In this contribution, I discuss the position of persons who enter or leave the country, since for them a residence requirement can be problematic. Since, in particular, the EU coordination law is meant to address the position of mobile persons, it is of particular relevance to study the impact this has had, and still has, on residencebased schemes. Do mobile persons have adequate protection under residence-based schemes? Did the schemes have to be changed as a result of the application of the coordination rules? And are the schemes adequately protected although mobile persons have access to them?

The article contains accounts of the following residence-based schemes: the oldage pension scheme, the scheme for special non-contributory benefits and the health care system. The term 'residence' is defined at the outset since it is a major instrument for controlling access to the schemes.

\section{THE DEFINITION OF RESIDENCE}

The term 'residence' is an important criterion for access to, and for insurance in, residence-based schemes. Fortunately, by cross referencing in the Acts, the criteria for residence are applied in the same way across insurance and other residence-based schemes. For example, Article 2 of the Health Care Act (Zorgverzekeringswet, ZVW) 
refers to the term 'residence' as defined in the Act on Long-term Care (Wet op de langdurige zorg). This ensures that the term is interpreted the same way. Other Acts, such as the Act for the Young Disabled (Wet Wajong), do not use cross referencing but simply provide that a resident is a person who lives in the Netherlands.

In order to ensure that there is no tension between the provisions on who is covered by the national residence Act concerned and international or European law, each Act has a provision giving priority to international and European law (for example, Article 6a of the Act on Old-Age Pensions states that: 'persons shall not be considered to be insured persons if, by virtue of a treaty or convention or a decision of an organisation of public international law, the legislation of another State applies to them').

The term 'residence' has been interpreted in case law and the results are set out in published policy rules of the benefit administration (Sociale Verzekeringsbank, $S V B$ ), which can be found on its website (www.svb.nl). These policy rules provide that a person is a resident of the Netherlands when s/he lives in the Netherlands. Whether or not this is the case depends on the circumstances of the case. This means, in general, that there has to be a durable link of a personal nature between this person and the Netherlands. Whether there is such link has to be considered on the basis of all relevant facts and circumstances of the case. ${ }^{1}$ Factors such as where the person lives and works, where her/his family lives, and registration in the civil registry are all taken into account. In particular, the duration of the residence is relevant. This means that short stays do not lead to residency. For accepting a durable link also the way the person earns her/his income is taken into account. Working as an employee or selfemployed person often shows a durable link with the country.

The criteria for residency have remained more or less the same over time. An important change of the laws was, however, the exclusion in the 1990s of persons who do not have a permanent residence permit for the Netherlands. ${ }^{2}$ These persons are not considered as residents. Non-residents are insured for a residence-based scheme if they are subject to the Dutch Law on Tax on Wages (Wet op de loonbelasting) on the ground that they are employed in the Netherlands. For example, a person who works in the Netherlands but lives in Belgium or Germany is covered by the Dutch Old-Age pension Act.

The inclusion of persons working as employees in the Netherlands has been part of the residence Acts from the very beginning (since 1957, for the Old-Age Pension Act). As a result, there is a natural link with the coordination rules, since these determine the legislation of the country where one works as being applicable on the basis of the 'country of employment principle' (currently Article 11(2) of Regulation 883/2004). As a result, both on the basis of national law and on the basis of the Coordination

\footnotetext{
1 Hoge Raad (Supreme Court) 21 January 2011 (ECLI:NL:HR:2011:BP1466) and Hoge Raad 4 March 2011 (ECLI:NL:HR:2011:BP6285).

2 The so-called Koppelingswet (Linking Act), which links entitlement to benefit or insurance to legal status.
} 
Regulation, a person working as an employee in the Netherlands is covered by a residence-based scheme, even if s/he does not live in the country. Coordination rules also address situations not foreseen in the national scheme (for instance, in the case of a person working in two countries), ${ }^{3}$ but basically the effect of the coordination rules is not an alien concept for the Dutch residence-based schemes.

The extension and restriction of the group of persons insured in residence-based schemes are regulated in a general decree based on the Acts (Besluit uitbreiding en beperking kring verzekerden volksverzekering, $B U B)$, Decree on the extension and restriction of the personal scope of residence-based insurance schemes). The coverage is extended to categories of residents on the grounds that they only live abroad temporarily or that they still receive their wages from the Netherlands. Excluded from coverage on the basis of the $B U B$ are, among other categories, foreign diplomats.

Article 24 of the Decree authorises the SVB to deviate from the rules of the Decree in the case of hardship exclusively resulting from compulsory insurance or exclusion from insurance (the so-called Hardship Clause).

\section{OLD-AGE PENSIONS}

\subsection{INTRODUCTION}

The emergence of residence-based schemes must be seen in its historical context. In the Netherlands, before the Second World War, there was considerable reluctance to introducing compulsory public social insurance. Christian Parties had a large number of seats in Parliament and they favoured a limited role for the State, among other reasons since they wanted to organise their own community (including health care insurance, health, education and trade unions). They stuck rigidly to the principle that each religious denomination should have responsibility for its own people. Only if there were legal grounds for making insurance compulsory could it be introduced by the State (in the next section, an example of such a legal ground is given). The discussion of legal grounds is also concerned with financing since insurance implies that the insured person and (in particular) the employer has to pay contributions. Therefore, there had to be a good argument for the State to impose compulsory contributions (i.e. 'to deprive employees and employers of their resources').

At the beginning of the $20^{\text {th }}$ Century it was acknowledged that, for workers, legal grounds existed for imposing statutory schemes. The grounds for introducing public insurance for work accidents (Ongevallenwet) was that workers suffered industrial accidents as part of the production process, and the production process was essential for society. A ground for introducing a sickness benefit scheme (Ziektewet) was that social security benefits can be seen as deferred wages. Both grounds implied that self-

$3 \quad$ See Kuijpers judgment, Case 276/81, Kuijpers [1982] ECR 3027. 
employed and non-active persons should not be covered by the insurance schemes. The Poor Law (and support by private organisations) was their only resort.

The Second World War and the Beveridge Report ${ }^{4}$ changed this thinking. It argued that poverty should be erased, and considered that the State should be responsible for the welfare of all. Inspired by the Beveridge Report, the Dutch government established the so-called Commission Van Rhijn, which outlined the foundations of the future Dutch social security system. Its report was published as Sociale Zekerheid (Social Security). ${ }^{5}$ The Commission proposed a new legal ground, which was very important for the development of Dutch social security, namely that the Community, organised in the State, is responsible for social security and for the protection against poverty of all its members, on the condition that they do all they can reasonably do to provide for their own protection through their own efforts. ${ }^{6}$ This legal ground was accepted by the government and made it possible to extend the scope of the social security system beyond the category of employees.

This was very important for the development of the old-age insurance, since it could now cover people other than employees. Nevertheless, there were important discussions on how the personal scope of the old-age insurance was to be defined. Should only self-employed people with a low income be insured, or should the full population be covered? After long discussions it was decided that the old-age scheme was to be a residence-based insurance scheme, covering all residents. This led to the Dutch statutory scheme for old-age pensions (Algemene Ouderdomswet, AOW, General Old-Age Pensions Law), adopted in 1956. It came into force on 1 January 1957, in the same year as the Treaty on the European Economic Community (EEC) was adopted and one year before EEC Regulation 3 on the coordination of social security schemes. ${ }^{7}$

The AOW covers all residents of the Netherlands and those who are subject to the tax on wages in this country. ${ }^{8}$ The pensions paid on the basis of the AOW are financed mainly from contributions (and partly from taxes). Persons with no income do not have to pay contributions, but are still insured.

Pensions are flat-rate and not means-tested, which means that neither the income (from work or from other pensions) nor the capital of the claimant are taken into account. The level of the pension depends on the type of household, where a

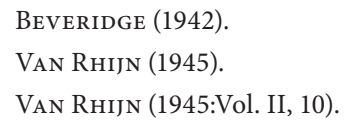

This Regulation was made in order to ensure, inter alia, that persons can aggregate periods of employment or work in order to claim benefits, that they can export benefits and that the applicable legislation is determined (elements of coordination of social security). These provisions apply only to persons, benefits and the territory within the scope of the Regulation.

8 A reminder of the strong opposition to compulsory insurance and public interference can still be found in the rule that persons with objections based on conscience can be exempted from paying insurance contributions. Instead, they pay taxes of the same amount, but without being covered for the risk. 
distinction is made between single persons, single persons with a child under 18 , and cohabitating persons. ${ }^{9}$ Since the pension is not means-tested, it is paid to everyone who has insured years (see next section). Although it was meant to erase poverty for those in old age, it is not limited to being a poverty scheme. It can be topped up by a (non-statutory) occupational pension (based on agreements by social partners), but it nevertheless constitutes an important part of the total income for quite a number of people.

\subsection{THE PRO-RATA SYSTEM OF THE OLD-AGE BENEFITS ACT AND THE COORDINATION REGULATION}

The level of benefit depends on the number of years for which a person has been insured under the AOW. The relationship with residence is clear: a year of residence amounts to 2 per cent of the full benefit that is payable for the category to which the person belongs. Residence during a year (as described in Section 2) is sufficient for acquiring rights based on that year, i.e. a person who has no income in a year, and for this reason does not have to pay contributions, still acquires pension rights based on that year (i.e. 2 per cent of the full benefit). ${ }^{10}$

A full benefit is paid to persons who have been insured for fifty years, i.e. between the ages of 15 and 65. This means that a person who has not been insured for every year between the ages of 15 and 65 has a lower pension than the full rate. However, since this rule would mean that no one would have a full pension until 50 years after the introduction of the Act (2007), there is also a system of transitional advantages, which means that the years before 1957 are credited. However this credit is limited to persons with Dutch nationality who lived from their $59^{\text {th }}$ to $65^{\text {th }}$ year in the Netherlands, and to some other categories who are equated with Dutch persons. ${ }^{11}$

The rules mean, for example, that a person who has been living in the Netherlands between the ages of 15 and 25 and who works in Germany until s/he becomes 65 acquires a Dutch pension of $10 \times 2=20$ per cent. If s/he was covered (using this example) by a German scheme, s/he will also have a pro-rata German pension, which may compensate for the reduction in the Dutch pension. This pro-rata system was in the Dutch Act from its inception and mentioned, without much explanation, in the travaux preparatoires. It was probably assumed that persons acquired pension rights in the country where they worked when they were not insured in the Netherlands, and the pro-rata arrangements were meant to avoid an overlap of insurance/pensions.

$9 \quad$ Cohabitating claimants each receive 50 per cent of the applicable rate (set at the level of the mount wage); unmarried claimants with a child under 18 receive 90 per cent and single claimants receive 70 per cent of this amount.

10 Only in the case of deliberate non-payment of due contributions in a year does one not acquire pension rights for that year.

11 Annex VI to Coordination Regulation 1408/71 extended this rule to EU nationals, but kept the condition on residence in the last 6 years before pension age intact. This was accepted by the Court of Justice, Case 293/88, Winter-Lutzins, [1990] ECR 1623. 
However, a person who spends her/his time in a country where s/he is not insured for pension has no such provision from abroad that compensates for the reduced Dutch pension. This situation actually occurs, in particular with some categories of thirdcountry nationals (in particular with migrant workers who came to the Netherlands in the 1960s and 1970s from Turkey and Morocco), since they came from countries with no or low (or not exportable) pensions.

Persons with a pension (and other income) below the applicable public assistance level also receive a public assistance supplement that ensures that they reach a subsistence level. Since the levels of AOW and Participation (Social Assistance) Act are linked, the person receives basically the same income as under a full AOW benefit. However, income and other pensions (such as supplementary occupational ones) and capital (such as houses) are taken into account, and also those of any partner, so that may still mean that the claimant is worse off than a person who has spent all his/her life in the Netherlands.

In order to make it easier for the persons concerned to obtain a top-up through public assistance, the benefit administration of the Old-Age Pensions Act (the SVB) pays this on its own initiative to the persons concerned (so that they do not have to apply for these benefits from the municipality, which is the administrative body for public assistance).

There are some differences between the Old-Age Pensions Act and the Coordination Regulation. The Act limits itself to defining which categories of nonresidents are covered, i.e. persons subject to the wage tax in the Netherlands, and does not mention self-employed persons who work in the Netherlands who do not reside there. When the Act was adopted, there was no discrepancy in the coordination rules, since self-employed persons did not fall under the personal scope of the Coordination Regulation before 1981. As a result of the amended Regulation, since $1981^{12}$ a selfemployed person not residing in the Netherlands, but working in the country has been covered by residence-based schemes. As a result, the condition in the Dutch scheme that a person has to be resident is overruled by the Regulation. ${ }^{13}$ However, the fact that non-resident employees were already insured if they were subject to the Dutch law of tax on wages means that this infringement of the residence principle is not all that radical.

It was decided in the Kits van Heiningen judgment that persons are covered by the legislation of a State regardless of the number of hours of work they do. So persons who work very short hours are also covered. In the case of a person from another Member State who is seeking work in the Netherlands, it cannot usually be said that $\mathrm{s} /$ he is already living in the Netherlands, and thus the legislation of the country where s/he lives still applies (Article 11(3e) Coordination Regulation). Consequently, s/he is not covered for the AOW, which is advantageous for him or her, since otherwise s/he

\footnotetext{
12 Regulation $1390 / 81$ of 12 May 1981.

13 Confirmed in Case 276/81, Kuijpers [1982] ECR 3027.
} 
would have to pay contributions, whereas, if s/he fails to find work, the amount of the pension s/he will acquire will be too small to be paid.

\subsection{LOSS OF PROTECTION AS RESULT OF APPLICATION OF THE REGULATION}

The effect of the Coordination Regulation that the system of the country of employment replaces the system of the country of residence does not, in principle, lead to problematic results. The difference in conflict rules - between the country of employment principle of the Coordination Regulation and the residence principle of the residence-based schemes - is solved by clear rules for determining the applicable legislation.

Such conflicts might occur if a national residence-based scheme provides for a full pension when one reaches pensionable age under such a system (e.g. in some Nordic countries in the past ${ }^{14}$, whereas the Coordination Regulation provides for a pro-rata system. However, in the Dutch system, pro-rata calculation of the pension has always been part of the AOW.

Problems do occur, however, if the system of the applicable country does not provide for any protection, and the person concerned lives in the Netherlands. In this case, s/he would have been protected under the national rules alone, but the coordination rules deprive her/him of insurance for the Dutch scheme and s/he loses rights to benefit. As a result, the person is worse off as a result of the application of the Regulation.

There is considerable case law on this issue from the Court of Justice. A very early case was Nonnenmacher. ${ }^{15}$ This case did not concern old-age benefits but, rather, survivors' benefits under the Dutch Algemene Weduwen en Wezen wet (General Widows and Orphans Act). This Act was adopted two years after the AOW and was also a residence-based scheme. For entitlement to benefit it required that the deceased person had to be insured for the scheme at the time of death. In this case the insured person (Mr. Nonnenmacher) worked in the Netherlands until 1 September 1959, when he obtained a job in France. He worked in France until his death, one and half months later, and, during this period, he resided in the Netherlands. As a result of his work in France, however, he became subject to the French social security system, which did not include a widow's pension for his wife. The question was whether his wife (Mrs. Nonnenmacher) was entitled to a Dutch widow's pension although her husband was not covered by the Dutch system at the time of his death.

The national court asked the Court of Justice whether the Coordination Regulation prevented Mr. Nonnenmacher from being subject to legislation in two countries at the time of his death, in other words, it addressed the exclusive effect of the rules for

\footnotetext{
14 See Sakslin (2000) and KoоtKas (in this issue).

15 Case 92/63, [1964] ECR 282.
} 
determining the legislation applicable of the Coordination Regulation. The answer was important for Mrs. Nonnenmacher, as an exclusive effect of the conflict rules meant that she would be without a pension. Before the Regulation came into force (October 1958), the problem would not have occurred, since Mr. Nonnenmacher was still residing in the Netherlands at the time of his death and application of national rules alone would have led to entitlement to the benefit. ${ }^{16}$

Mrs. Nonnenmacher was, however, saved by the Court of Justice. The applicable Coordination Regulation at the time was Regulation 3, and in this Regulation the rules on determining the applicable legislation were not worded in such a way that their exclusive effect was inescapable. The General Widows and Orphans Act itself did not exclude persons from its coverage when they were subject to a foreign system; this was not regulated until $1989^{17}$ when a new Article 6a was inserted into the Act (see Section 2 supra for the text).

The Court considered that, in the absence of specific clauses, the plurality of benefits under two national laws was not prevented. Article 12 of Regulation 3 did not prohibit the application of the law of a Member State other than the one on whose territory the person concerned worked, unless it compelled this person to contribute to the financing of a social security institution which did not grant any extra benefits for the same risk and the same period. ${ }^{18}$

Regulations 1408/71 and 883/2004 no longer allowed such an interpretation The wording of Article 13 of Regulation 1408/71 and Article 11 of Regulation 883/2004 make clear that the rules for determining the applicable legislation have exclusive effect. Article 11 of Regulation 883/2004, for instance, provides that persons to whom the Regulation applies shall be subject to the legislation of a single Member State only.

The exclusive effect was confirmed by the Court in the Ten Holder judgment. ${ }^{19}$ Ms. Ten Holder, a woman of Dutch nationality, had been employed in Germany for some time. When she became ill, she was granted German sickness benefit, Krankengeld. After a time, she returned to the Netherlands. When the maximum duration of Krankengeld had expired, she applied for a Dutch invalidity benefit, since she did not satisfy the qualifying conditions for a German incapacity benefit. Since the Dutch disability scheme was at that time a residence-based scheme, she would have been entitled to this benefit on the basis of mere residence, provided that the Dutch legislation was applicable. The Court held, however, that the legislation of the former State of employment, i.e. Germany, was still applicable; and that this was the case until the person concerned entered employment in another Member State. The effect of this interpretation was that Ms. Ten Holder was not entitled to the Dutch disability benefit

\footnotetext{
16 Note that, because the Widows and Orphans Benefits Act came into force on 1 October 1959, two weeks before he died, Mrs Nonnenmacher was not deprived of rights she had already expected for a long time.

17 Law of 29 April 1998 (Stb. 1998, No. 267).

18 Nonnenmacher judgment, [1964] ECR 282.

19 Case 302/84, [1986] ECR 1821.
} 
and the fact that she did not satisfy the conditions of German disability benefit was irrelevant.

The Court held, in considerations 21 and 22 of the Ten Holder judgment, that the provisions of Title II of the Coordination Regulation constituted a complete system of conflict rules, the effect of which is to divest the legislature of each Member State of the power to determine the ambit and the conditions for the application of its national legislation in so far as the persons who are subject to it and the territory within which the provisions of national law take effect are concerned. Member States are not entitled, the Court continued, to determine the extent to which their own legislation, or that of another Member State, is applicable since they are under an obligation to comply with the provisions of Community law in force. That rule is not at variance with its decisions, the Court added, in particular with the Petroni judgment, ${ }^{20}$ in which it was decided that the application of Regulation 1408/71 cannot entail the loss of rights acquired exclusively under national legislation. That Petroni principle does not apply to the rules for determining the applicable legislation, but it does apply to the rules of Community law on the overlapping of benefits provided for by different national legislative systems. It cannot therefore have the effect, contrary to Article 13(1) of Regulation 1408/71, of causing a person to be insured over the same period under the legislation of more than one Member State, regardless of the obligations to contribute or of any other costs which may result from this for that person. Thus, the Court made clear that a Member State is no longer free to pay benefits if its legislation is not applicable according to the rules for determining the applicable legislation.

The Ten Holder judgment thus limited, and in some cases extended, the scope of the residence-based schemes. Ms. Ten Holder, who entered Dutch society while still subject to a foreign system, in spite of not working there anymore, did not acquire pension rights and the right to disability benefits in the Netherlands. The mirror effect is that persons who were covered by the Dutch system remained insured under this system although they no longer resided or worked in the Netherlands until they became subject to a new scheme. If the new scheme was based on employment and they did not work, they did not become subject to that scheme. Since only persons with an income had to pay contributions to the Dutch residence-based schemes, this could mean 'free insurance' (or, in other words, solidarity for this person) even though the persons concerned no longer had a link with the Netherlands. These problems occurred for residence-based schemes since the rules for determining the applicable legislation overruled the residence-based requirements of these schemes, and these were the only conflict rules for opening or closing access to the scheme.

After the Ten Holder judgment alarming articles on the expected collapse of residence-based schemes appeared in legal journals. ${ }^{21}$ These problems could not

\footnotetext{
20 Case 24/75, Petroni, [1975] ECR 1149.

21 See, for example, Levelt-Overmars (1988).
} 
simply be solved by adjusting the residence-based schemes, since they concerned a coordination issue. Thus the Daalmeijer judgment ${ }^{22}$ of the Court of Justice was welcome because it ruled that Article 13 of Regulation 1408/71 no longer applied to a person who had permanently terminated her/his working activities. The objective of Article 13 was to solve conflicts of law that can occur when, for a certain period, the place where a person resides and the place where s/he works are not in the same Member State. These conflicts no longer occur for persons who have permanently terminated their working activities.

Prior to the Daalmeijer judgment, the European Commission had already taken the initiative of making an amending Regulation in order to solve the problems resulting from the Ten Holder ruling. This Regulation was adopted in 1992 and introduced Article 13(2)(f) to Regulation 1408/71. ${ }^{23}$ This ruled that, in the case of a person who was not engaged in employment and who ceased to be subject to the legislation of a Member State without being subject to the legislation of another State, the legislation of the State of residence became applicable. ${ }^{24}$ The new Article left it to the Member States to define when a person was no longer covered by that State if s/he did not work there anymore. ${ }^{25}$

The rules on persons who are no longer working are slightly different in Regulation $883 / 2004$, but the principle of exclusive effect has been maintained. However, the question of the effects of this principle is still subject of discussion as a result of the Bosmann judgment. ${ }^{26}$ This case concerned a Belgian woman, working in the Netherlands, and residing in Germany. Since her two children were over the age of 18, they were not eligible for family benefits (which are a residence-based scheme under Dutch law) that limited eligibility to those under the age of 18 (student grants are available for older children but these could not be accessed by the Bosmann children since they lived abroad).

The Court ruled that EU law did not require the competent German authorities to grant Ms. Bosmann German family benefits, since she was insured under the Netherlands system. However, it added, the possibility of such a grant cannot be excluded because, under the German legislation, Ms. Bosmann may be entitled to child benefit solely because of her residence in Germany, although this was for the national court to determine. For this purpose, the Court referred to the legal basis of the Regulation - Article 42 EC (now Article 48 TFEU) - which aims to facilitate

Case 245/88, [1991] ECR I-555.

COM (1990) 335 of 24 July 1990, OJ 1992 L 206.

See Verschueren (2007).

25 In the Kuusijärvi judgment (Case 275/96, [1998] ECR I-3419) the Court ruled that Article 13(2)(f) not only applied in the case of a person who had permanently ceased his occupational activities, but as soon as the person was no longer subject to national law in accordance with the provisions of that law. Regulation $883 / 2004$ defines more precisely when the legislation of the previous State is no longer applicable, so the Regulation 1408/71 rules and Kuusijärvi case law has become outdated. 
freedom of movement for workers and entails, in particular, that migrant workers must not lose their right to social security benefits or have the amount of those benefits reduced because they have exercised the right to freedom of movement conferred on them by the Treaty (consideration 29). In light of these factors, the Court responded, the Member State of residence cannot be deprived of the right to grant child benefit to those who are resident within its territory.

Thus, it is still possible to obtain benefits or to be covered in two countries at the same time, although it is not entirely clear yet under what conditions. This issue was also raised for Dutch residence-based schemes. The problem here exists, in particular, for those who are residing in the Netherlands, but working in Germany. In Germany small jobs are excluded from, inter alia, old-age insurance and, as a result of the coordination rules, persons engaged in them are not covered by the Dutch residencebased schemes anymore. As a result, the persons concerned are insured neither in the country of work nor in the country of residence.

The Dutch Social Security Court was asked by the persons concerned for a decision to solve this problem. It addressed questions to the Court of Justice and this led to the Franzen judgment, concerning joint cases on several residence-based schemes. ${ }^{27}$ In these cases, the provision, mentioned above, providing that a person is not insured under the Act when this follows from international law (e.g. Article 6a AOW) was relevant. At first sight this provision seemed to imply that the Bosmann judgment was not of any help to Ms. Franzen and the other applicants in this case, since national law itself provides that it does not apply when another system applies (see section 2 supra).

However, the Court of Justice took the following approach. It considered that the personal scope of the residence-based schemes concerned is regulated by a special Decree (BUB) that has a hardship clause, which empowers the SVB (the organisation administering the Old-Age Pension Act), to derogate in certain cases from the other provisions of that Decree in order to remedy an unacceptable degree of unfairness that might arise from the insurance obligation or the exclusion therefrom by virtue of that Decree, or in the framework of the Decree.

The Court of Justice considered that the referring court had made it clear that, if the Coordination Regulation does not prevent the application of the Dutch legislation, then it is for the referring court to disregard the exclusion clause and to apply the hardship clause provided for in the BUB in order to remedy any unacceptable unfairness that might arise (consideration 56). Here we see a problem that the Decree gives the power to the benefit administration and the Court of Justice interprets this as the power of the national court.

The Court of Justice then considered that, in this case, it appeared that the substantive conditions for granting the old-age benefits under the legislation of the Member State of residence were fulfilled, since the persons resided in the Netherlands. The granting of those benefits would not, in the event of the simultaneous application

$27 \quad$ Case C-382/13, ECLI:EU:C:2015:261. 
of the legislation of the State of residence and State of employment, give rise to an overlapping of the same form of family benefits in relation to the same period. After all, they were in casual employment in Germany, without being affiliated to the German old-age pension scheme because of their low incomes (consideration 63). Consequently, the Court ruled that it must be found, as was held in the Bosmann case, that the rules of determining the applicable legislation did not preclude granting Dutch benefit.

Thus two elements are relevant: the exclusion provided for in Article $6 \mathrm{a}(\mathrm{b})$ aims to transpose the single State principle into national legislation. However, this is not relevant to entitlement to residence-based schemes, since the mere fact of residence in the Netherlands is sufficient for establishing entitlement to child benefits. Secondly, the facts of Ms. Franzen's case did not present an overlapping of the same form of family benefit in relation to the same period of insurance (consideration 65).

The judgment is somewhat confusing since the Court of Justice argued that the referring judge had said the hardship clause would be applied although this was not said by the national court. ${ }^{28}$ Applying the hardship clause is a competence of the benefit administration and not of the court, although the latter can to some extent test the use that is made of it. ${ }^{29}$ There is therefore uncertainty over whether this was a decisive element for the solution presented by the Court of Justice. However, the judgment does imply that, despite Article 6(a), the benefit administration can pay residence-based benefits if the conditions under national law are satisfied.

There is also a remarkable element in this case. From the national judgment in which the questions to the Court of Justice were worded, it appeared that Ms. Franzen refused the offer of the SVB to try to make an Article 16 Agreement ensuring that she would be covered by the Dutch system. In case of such coverage, she would have had to pay health care insurance contributions, which she did not want to do, since these were high in comparison with the pension rights she would acquire. Whatever the exact situation was, it is clear that, in addition to (lack of) coverage and poverty due to gaps in the insurance, for some persons it is also a matter of shopping between the systems. This is an element that has not been completely solved yet.

The approach of the Court of Justice in the Franzen seems to have had a limited effect, since it was based on the discretion that a national system gives to the benefit administration to pay benefits even if it is not the competent system. The fundamental problem is that, if a country (in this case. Germany) does not provide protection to particular groups, this poses problems for other countries. If the country concerned does not want to change this, an Article 16 solution is preferable, since it remedies the effects of the rules for determining the applicable legislation. Shopping between

28 CRvB 1 July 2013, ECLI:NL:CRVB:2013:783.

29 In the Hendrix judgment (Case C-287/05, [2007] ECR I-6909), a problem occurred in not exactly referring precisely to the national law: the Court of Justice considered that use can be made of the hardship clause in the Disability Act involved, but, at the time when the case arose, the Act did not yet contain a hardship clause. 
systems is, of course, a completely different issue from countering the adverse effects of the coordination rules. It is worth discussing the use of Article 16 more broadly. Could it be a way of solving the problems with the conflict rules? Should the individual have more say over when Article 16 agreements are made or not? These are interesting questions for future research.

\section{PUBLIC ASSISTANCE AND NON-CONTRIBUTORY BENEFIT SCHEMES}

\subsection{PUBLIC ASSISTANCE}

Public assistance is not within the material scope of the Coordination Regulation, so there is no conflict between the Act and the Regulation. Currently, social assistance is provided on the basis of the Participatiewet (Participation Act). Benefit is payable to persons with Dutch nationality and foreigners living legally in the Netherlands in accordance with Articles 8(a)-(e) and (l) of the Aliens Act, with the exception of the situations mentioned in Article 24(2) of Directive 2004/38. The latter provision provides that the host Member State shall not be obliged to confer entitlement to social assistance during the first three months of residence or, where appropriate, the longer period provided for in Article 14(4)(b). The latter Article provides that EU citizens and their family members may not be expelled for as long as they can provide evidence that they are continuing to seek employment and that they have a genuine chance of being engaged. By referring to Article 24(2) of the Directive, the Act makes sure that it is consistent with the Directive, in other words, that it is not more restrictive than the applicable EU law. ${ }^{30}$ This provision thus excludes persons seeking work while not having worked before in the Netherlands.

If EU citizens and/or their family members apply for public assistance benefits during the period between three months and five years after entering the country, the immigration authorities may terminate their residence permit. Terminating the residence permit is justified when the applicant becomes an unreasonable burden on the system. For this purpose, it must be taken into account that if EU citizens and their family members claim social assistance (benefits or lodging), the policy is that the longer they reside in the Netherlands the less they are regarded as an unreasonable burden.

For persons seeking refugee status a special scheme exists. This is covered by the Asylum Seekers' (Provision) Regulation, which provides minimum support. However, after a person has been granted asylum status and lives by herself/himself, the conditions for claiming public assistance and for access to insurance benefits under the residence-based schemes are satisfied.

30 See HARRIS (in this issue) on the discussions about the UK rules on job-seekers allowance versus the Directive. 


\subsection{SPECIAL NON-CONTRIBUTORY BENEFITS}

There are also Regulations other than the Participatiewet guaranteeing a subsistence income. Their purpose is to prevent certain groups from having to rely on the Participatiewet, which has, aside from a means test on income, a means-test on capital. For some groups (for example, elderly persons) this capital test was seen as undesirable because it affects savings and capital and, particularly in the case of home owners, this was seen as problematic, as they would have to take out a mortgage loan on their house in favour of the benefit administration.

One of these schemes is the Supplementary Benefits Act (Toeslagenwet, $T W$ ), to which persons who receive an employees' insurance benefit, e.g. unemployment benefit or disability benefit, are entitled if these are below subsistence level. These benefits may, due to the fact that their level is related to the previously earned wage, be paid at levels below the social minimum and, in such cases, a supplement is payable.

The Toeslagenwet falls within the scope of the Coordination Regulation, since it is linked to other schemes that are within its scope. In 1998, the Act was registered as providing special non-contributory benefits, and since then these supplements are no longer exportable. ${ }^{31}$

In the Coordination Regulation, special non-contributory benefits are regulated by Article 70 of Regulation 883/2004. For these benefits, the export provision (Article 7 of this Regulation) does not apply and the other Chapters, such as the rules on the prorata calculation, do not apply either. Article 70(4) provides that these benefits shall be provided exclusively in the Member State in which the person concerned resides, in accordance with its legislation, and that they have to be provided by and at the expense of the institution in the place of residence. Consequently, the special noncontributory benefits are not exportable and the legislation of the State of residence determines whether a person receives these benefits or not.

This rule has negative effects for persons leaving a Member State who are entitled to such a benefit since they are no longer entitled to it as long as they stay outside the country. The rule has advantages for persons coming from outside a Member State, as they become entitled to such a benefit, even if the risk (e.g. disability) had already materialised when they were outside the territory of the country.

Section (b) of Article 5 states that where, under the legislation of the competent Member State, legal effects are attributed to the occurrence of certain facts or events, that Member State shall take account of such facts or events occurring in any Member State as though they had taken place in its own territory. Thus, if a scheme requires that a person is entitled to, for example, a benefit for people who became disabled before reaching the age of 18 on condition that they were residing in that country at that time, this condition is satisfied if the person resided at that age in another Member State. Another effect of the principle of equal treatment of benefits and facts

By Regulation 1223/98 of 4 June 1998, OJ L of 13 June 1998: 1. 
applies to pensions granted in another Member State that the person concerned would wish to supplement by a special non-contributory cash benefit. However there is no specific case law of the Court of Justice on the benefits of the Toeslagenwet. ${ }^{32}$

Regarding the Wajong benefit (under the Act for the Young Disabled), there have been some cases before the Court of Justice. Benefits payable under this Act are meant for persons who were already disabled before they reached the age of 18 (and for persons who became incapacitated for work when they were students). Persons satisfying one of these conditions can receive the benefit until they reach the age of 65, as long as they continue to fulfil the conditions of the Act. In 2015 the entitlement conditions were tightened considerably and only those persons who are completely unable to work are now eligible.

The Wajong benefit was listed as a special non-contributory benefit for the Coordination Regulation in 1998, together with the Toeslagenwet (both Toeslagenwet and Wajong benefits were freely exportable before this change). As a result, the Wajong benefit is no longer exportable. However, the Act has a hardship clause for those cases where hardship would otherwise occur, in which case the benefit is exportable. An example is where a person completely who is dependent on her/his parents returns with them to their country of origin. Another example is that of marriage to a person who goes abroad. In the view of the Dutch legislator, losing all benefit rights in such personal circumstances, where there are few opportunities for the disabled person to stay in the Netherlands, would cause hardship.

There was some doubt about whether the Wajong scheme was really a special non-contributory scheme. However, in the Kersbergen-Lap and Dams-Schipper case $^{33}$ the Court of Justice decided that the Wajong benefit was correctly listed in the Annex of the Regulation as a special non-contributory benefit. By guaranteeing a minimum income to a socially disadvantaged group (disabled young people), the Wajong benefit is, by its nature, social assistance and this can be justified on economic and social grounds (consideration 31). Moreover, it is granted according to objective criteria defined by law. Furthermore, it is closely linked to the socioeconomic situation in the Netherlands since it is based on the minimum wage and the standard of living.

A remarkable decision on the Wajong benefit was the Hendrix judgment. ${ }^{34}$ The dispute in this case had arisen since Mr. Hendrix lost his Wajong benefit when he moved to Belgium and, as a result of this loss of benefit, he also lost his job. The reason for this was that the grant of Wajong benefit meant that the employer was

\footnotetext{
32 It is remarkable, however, that for Turkish persons the Toeslagenwet remains exportable due to the applicability of Decision 3/80, as confirmed by the Court of Justice in the Akdas judgment (Case 485/07 [2011] ECR I-4499). Decision 3/80 was largely the same as Regulation 1408/71, but since its adoption never updated. As a result, there are no specific provisions on special non-contributory benefits in Regulation 3/80.

33 Case C-154/05, [2006] ECR I-6249.

34 Case C-287/05, [2007] ECR I-6909.
} 
relieved from the obligation to pay the statutory minimum wage, whereupon the Wajong benefit supplemented the actually paid wage up to the minimum wage level. Although technically speaking it was not a wage cost subsidy, it served as a subsidy for employers to employ disabled workers. Since, after termination of the right to Wajong benefit, the employer was obliged to pay the minimum wage, Mr. Hendrix was dismissed.

The Court considered that the Wajong benefit was a special non-contributory benefit. However, it also held that the provisions of the Coordination Regulation that was enacted to give effect to Article 48 TFEU must be interpreted in the light of the objective of that Article. This is to contribute to the establishment of the greatest possible freedom of movement for migrant workers. It follows that the condition of residence attached to receipt of the Wajong benefit can be put forward against a person in the situation of Mr. Hendrix only if it is objectively justified and proportionate to the objective pursued. The Wajong benefit is closely linked to the socio-economic situation of the Member State concerned, as was already decided in KersbergenLap, and it follows that the condition of residence as such, laid down in the national legislation, is objectively justified. It is also necessary, the Court continued, that the application of such a condition does not entail an infringement of the rights which a person in the situation of Mr. Hendrix derives from freedom of movement for workers that goes beyond what is required to achieve the legitimate objective pursued by the national legislation. The hardship provision mentioned above expressly provides that the condition of residence may be waived when it leads to an 'unacceptable degree of unfairness' (although this provision was not part of the Act when the facts of the Kersbergen-Lap case were established).

The Court took this provision into account and decided that it was the responsibility of national courts to interpret, so far as possible, national law in conformity with the requirements of Community law (consideration 57). The referring court must therefore be satisfied, in the circumstances of the particular case, that the requirement of a condition of residence on national territory did not lead to such unfairness, taking into account the fact that Mr. Hendrix had exercised his right of freedom of movement as a worker and that he had maintained economic and social links to the Netherlands.

In the subsequent procedure, the Dutch court decided, taking into account this judgment that, in this case, the Wajong benefit had to be exported. ${ }^{35}$ This was because terminating the benefit in this case could result in the loss of a job, and this would be a serious impediment of the right of free movement.

In the introduction to this section the assimilation rule of Article 5 Regulation $883 / 2004$ was mentioned. This rule holds that the condition that a person has to be disabled before the age of 18 in the Netherlands can also be satisfied in another Member State. Since this was already the effect of Article 10(a)(4) of Regulation $1408 / 71$, it is not new. However, the personal scope of Regulation 883/2004 is broader 
than that of Regulation 1408/71. Under the latter Regulation, only employees and selfemployed persons were covered. Regulation 883/2004 covers all persons subject to a social security scheme.

For the Wajong benefit this is an important change, as many of the claimants are not workers. Thus, they could not invoke Regulation 1408/71 other than as a family member of a worker or self-employed person working in the Netherlands. Thus, if they went by themselves to live in the Netherlands they could not invoke the Regulation (unless they were workers themselves). Under the new Regulation, they can come to the Netherlands by themselves and invoke the assimilation rule and this could open the road to more persons coming than before.

A question then is whether, if a person goes to the Netherlands and claims the Wajong benefit, this means that $\mathrm{s} / \mathrm{he}$ can lose the right to reside, since s/he claims a public assistance benefit (see on these rules section 4.1 above). As mentioned above, claiming a public assistance benefit can, in some circumstances, affect the person's right to residence in a Member State. According to the Preamble of Directive 2004/38, persons exercising their right of residence should not become an unreasonable burden on the social assistance system of the host Member State during an initial period of residence. In the Brey case ${ }^{36}$ a non-contributory benefit was refused since the claimant did not have sufficient resources to establish lawful residence in Austria ${ }^{37}$

The Court considered that Article 70(4) of Regulation 883/2004 does not preclude national legislation from making the right to a special non-contributory cash benefit conditional on meeting the necessary requirements for obtaining the legal right of residence in the Member State concerned (consideration 42 and following). A benefit such as the compensatory supplement involved does indeed fall within the scope of Regulation 883/2004. However, this fact cannot, in and of itself, be decisive for the purposes of interpreting Directive 2004/38 on residence rights, since the objectives pursued by Regulation $883 / 2004$ are different to those pursued by the Directive. For the purposes of Directive 2004/38, the concept of a 'social assistance system' must be defined by reference to the objective pursued by that provision. Accordingly, the concept must be interpreted as covering all assistance introduced by public authorities, whether at national, regional or local level, that can be claimed by an individual who does not have resources sufficient to meet his own basic needs and the needs of his family and who, by reason of this fact, may become a burden on the public finances of the host Member State during his period of residence which could have consequences for the overall level of assistance which may be granted by that State.

Furthermore, in order to determine whether a person receiving social assistance has become an unreasonable burden on its social assistance system, the host Member State should, before adopting an expulsion measure, examine whether the person concerned is experiencing temporary difficulties and take into account the duration

\footnotetext{
36 Case C-140/12, Brey, ECLI:EU:C:2013:565.

37 See VERSCHUEREN (2014).
} 
of residence of the person concerned, his personal circumstances, and the amount of assistance that has already been granted to him. Also this must not automatically lead to an expulsion measure. ${ }^{38}$

In the Dano case it was confirmed that persons cannot claim a non-contributory benefit, even though it falls within the scope of Regulation $883 / 2004$, unless their residence complies with the conditions of Directive 2004/38. ${ }^{39}$ Verschueren discusses both a narrow and a broad interpretation of this judgment: are persons only excluded if they go to another Member State in order to obtain benefits or also in other situations ${ }^{20} \mathrm{He}$ is in favour of the first interpretation, which does not mean that all special non-contributory benefits should be classifie as social assistance.

In the later Alimanovic judgement, ${ }^{41}$ however, the Court of Justice determined that a jobseeker's allowance (a special non-contributory benefit) for persons who lost their jobs was social assistance. Although this benefit was intended to bring to an end, or to reduce the need for, social assistance, in particular through integration into the labour market, and was intended only to cover subsistence costs, the Court ruled that it was sufficient to note that the referring court had itself characterised the benefit at issue as a 'special non-contributory cash benefit' within the meaning of Article 70(2) of Regulation 883/2004. It stated that these benefits are intended to cover subsistence costs for persons who cannot cover the costs themselves and that they are not financed through contributions, but through tax revenue. The predominant function of these benefits is, in fact, to cover the minimum subsistence costs needed to lead a life in keeping with human dignity. This case law leaves little doubt that the Wajong benefits are to be considered as social assistance and that persons coming to the Netherlands and claiming this benefit can be refused benefit since they are not legally residing in the Netherlands according to Directive 2004/38.

In practice, no significant increase in the number of claimants of Wajong benefit from abroad has been reported. An explanation may be that a claimant has to be disabled before the age of 18 or a student, and that it is therefore not simply a job seekers allowance. Moreover, these young disabled persons may have practical problem in moving to another Member State, since they are often not able to travel and live by themselves.

In addition, the Wajong benefit has been reformed as of January 2015; now only fully and full disabled persons have access. This measure was taken in order to reduce influx into the system generally, so not particularly, or even not at all, in respect of foreigners.

\footnotetext{
$38 \quad$ See VAN DER Mei (2014).

39 Case C-333/13, EU:C:2014:2358.

40 Verschueren (2015b: 435).

41 Case C-67/14, EU:C:2015:597.
} 


\section{HEALTH CARE}

A third type of benefit to be discussed is health care. Since 2004, the Health Care Act (Zorgverzekeringswet, $Z V W)$ ) has covered all residents. Before this Act came into force, employees earning less than a certain amount were compulsorily covered by the Sickness Fund Act (Ziekenfondswet) and those who were not covered could buy private insurance (this was not compulsory). Thus, the introduction of the Health Care Act marked a substantial change from a system with an employees' scheme (of limited scope) to a general residence-based scheme. This Act, the $Z V W$, was deemed necessary, since the rise of technology and the greying of the population mean that the costs of medical care are expected to grow continuously. The Act is supposed to have some built-in elements which can control the costs more easily.

The $Z V W$ covers all residents and all persons subject to the wage tax in the Netherlands. A special position still exists for the family members of persons who work but do not reside in the Netherlands. They are covered by the Act on the basis of international Regulations, including Regulation 883/2004.

The $Z V W$ covers a much larger group than the Ziekenfondswet as it covers all persons regardless of their income. Pensioners who receive a Dutch pension and reside in another country are also subject to the new Act whereas, in the past, it was very well possible that they would not be eligible for statutory health care. If they receive a pension from the Netherlands only, they are covered by the $Z V W$ and they have to pay contributions in the Netherlands.

The Health Care Act basically requires those who are resident to buy private insurance from a private insurance company. The Act and the Regulations based on it specify the contents of the basic insurance that is provided by the insurance company, and thus ensure that insured persons are sufficiently protected. Health insurance is on offer from a large number of insurance companies. They (have to) offer the same basic insurance, i.e., the basic contents of the insurance are specified by law (although there may be differences in the extent to which insured persons can choose a care provider). The insurance companies have to determine the contribution rates and this is the major instrument of competition between them.

The second Act covering major medical risks is the Long-term Care Act (Wet langdurige zorg). This Act covers those parts of medical care that cannot be privately insured, or can only be covered by paying very high contributions, and includes long-term and chronic care (for example home care costs, prolonged hospitalisation, nursing home stays and care for the mentally disabled). It is a residence-based scheme and all residents of the Netherlands are automatically insured, that is, no action has to be undertaken in order to become insured. The criteria for residence are discussed in section 2 above.

Anyone who comes from abroad and settles in the Netherlands is insured under the Long-term Care Act and will consequently be eligible for benefits. However, a waiting period applies. The waiting period is one month for each year that the person 
was not insured in the Netherlands up to a maximum of 12 months. The waiting period applies for inpatient care which is deemed to be 'indicated' at the start of the insurance - that is for care that has already been established to be necessary and that is expected to be needed in the foreseeable future.

Persons who irregularly reside in the Netherlands are excluded from the Acts. However, if they receive treatment for urgent care and cannot pay for this, the costs are reimbursed by the State to the care provider at the rate of 80 per cent. There is frequently discussion about what is meant by urgent care. The reimbursement rules undoubtedly make treating these persons rather unattractive.

Persons who fail to pay contributions or to buy insurance are first given a fine (after 3 months). After 9 months, their insurance is purchased by the Zorginstituut Nederland (the national organisation that supports the quality of and access to health care) and they then have to pay contributions to this organisation. In this way, an attempt is made to ensure that no one who stays in the Netherlands legally is unprotected.

\subsection{THE HEALTH CARE ACT AND THE COORDINATION RULES}

The ZVW (Dutch Health Care Act) does not provide free health care. Instead, people have to be insured in order to claim health care. It is a contributory insurance scheme and those with low incomes receive a so-called 'care supplement' from the Tax Office. This system means that the question of who is a resident for the purpose of claiming health care raises few problems. However, there may be disputes about who is a resident when it comes to the obligation to buy insurance.

A special characteristic of the health care coordination rules is that members of the family are also covered by the health insurance of the competent state, unless they are insured in their own right. This means that persons not living in the Netherlands, whose spouse or parent works in the Netherlands (for example frontier workers) are covered by the Dutch system.

A special problem for the $Z V W$ was the position of pensioners. Before the Act came into force, many pensioners who were resident abroad were not covered by the Dutch system, since they were not covered by the Ziekenfondswet. After the ZVW came into force, those who had a Dutch pension were compulsorily covered and had to pay contributions. There were many cases on this subject. ${ }^{42}$ They show that, in residence-based schemes paid by tax there are sometimes measures that are deemed necessary for excluding people and that, in contributory schemes, cases can arise where persons do not want to be included.

42 See the Van Delft judgment (Case C-345/09, [2010] ECR I-09879); and Van der Helder judgment, Case C-321/12, EU:C:2013:648. 


\section{CONCLUSIONS}

Experience shows that the Dutch residence-based schemes do not necessarily clash with the free movement and coordination rules, in spite of the fact that the conflict rules of the national schemes are different from the coordination rules. The Netherlands was one of the founding States of the EEC and, since the other States did not have residence-based schemes at the time, the Dutch residence-based schemes were the first confront the coordination rules. Although this confrontation concerned fundamental elements - the difference between working and residence as the basis of conflict rules - the Dutch residence-based scheme did not have to be changed fundamentally as a result. The major reason was that the Old-Age Pension Act already adopted the pro-rata principle. As a result, it did not experience the problems faced by some Nordic schemes that all residents were entitled to a full pension when they reached pensionable age, a practice that could not be maintained in the EU coordination system.

Overall, it cannot be said that, as in the UK, the criteria for being a resident have been tightened in order to keep foreign migrants out of the system. The criteria were, on the whole, constructed in order to make sure that a person is not, at the same time, insured in another country, not with the purpose of keeping the person out of the system in order to protect the system against claims. Since the Dutch system is a contributory one, entrance to the scheme is not free. Indeed there are some cases mentioned in the previous sections about people who did not want to be included in the system or part of it. ${ }^{43}$

Having said this, it can also be seen that the Dutch system has, over time, become more focused on persons who are actually living in the country. For example, the possibility of staying insured by taking out voluntary insurance has been restricted (to 10 years). Also the export of benefits has been restricted, although this did not affect export to other EU Member States, as the Regulation does not allow this. A special position is that of Wajong benefit for the young disabled and the Toeslagenwet, for which export came to an end in the 1990s.

There were some effects that were not foreseen by the Dutch legislature, for example the effect of working in two countries simultaneously (the subject of the Kuijper judgment), and situations where the Coordination Regulation led to outcomes different from the national system. However, they did not lead to huge problems.

The pro-rata principle in the Old-Age Pension Act results in persons who make use of free movement not receiving the full benefits of the Dutch system. However, this is the result of the national rules, not of the impact of the coordination rules. By means of public assistance supplements persons without a sufficient income from another country can still achieve a basic level of benefit.

$43 \quad$ The pensioners in the previous section and Ms Franzen. 
Another effect of the application of the coordination rules is that persons residing in the Netherlands are excluded from coverage if they work in another country. This is problematic if the other country does not provide protection for the person concerned. This arose in Nonnenmacher; the coordination rules at the time were interpreted by the Court in such a way that they allowed the application of the system of a noncompetent State. However, the exclusive effect of the conflict rules was fully accepted in Ten Holder and Member States are even forbidden, it seems, to pay benefit if they are not the competent State. As a result of the Bosmann and Franzen judgments, an extended scope for coverage is now allowed if the national Act allows for this, but it is not clear what the final outcome of this development will be.

The Wajong benefit for the young disabled is a non-contributory system, and may therefore be more vulnerable to benefit tourism. Of course, it is available only for those who are already disabled by the age of 18 , which is an important selection criterion. Still, if there are cases of persons who settle in the Netherlands without a sufficient income of their own, this may affect their residence position. Whether, and when, this is the case, is still not clear. The benefit scheme was not adjusted to take account of this development, but instead was reformed to exclude people who are still able to work. The Dutch policy is more focused on activation than dealing with an influx of foreigners.

Finally, the health care system is based on contributions and for this reason the discussion is focused more on people who do not want to be included, because they have to pay contributions, than on persons who make use of the health care system as social tourists. As a result of the Coordination Regulation, persons living abroad with a Dutch pension are also covered (sometimes against their will).

Overall, the residence-based schemes discussed here have shown themselves to be capable of dealing with increases in the use of free movement, and also of economically inactive persons. The criteria for residence have not been really been sharpened recently. A major explanation is that these schemes are contributory. ${ }^{44}$

A scheme that is vulnerable as a scheme of first resort is public assistance (Participatiewet). Here it is not the residence condition that is decisive for eligibility (although one must live in the Netherlands), but the legal status (being Dutch or having permanent resident status). This excludes non-economically active persons during the first three months. After that, whether they constitute a burden for the system is investigated and, for this purpose, their expected period of stay in the Netherlands is important.

Although the system is certainly not without its problems, ${ }^{45}$ it follows from this account that it is possible to organise - as Beveridge proposed - a universal scheme that protects persons from want and is, to a large extent, not means-tested. It is

44 Indeed, it seems that most discussions on whether or not one is a resident occur with family benefits, a type of scheme not discussed here. It should be noted that family benefits are a tax financed residence-based scheme.

After all, in this article not all provisions were discussed, such as subsidies of rent. 
interesting to compare this with Harris' account of developments in the UK in this issue. The more the British contributory residence-based benefits were supplemented by means-tested provisions, the more the system became vulnerable to claims from persons of whom whether they 'belong to the system' has to be established, and the stricter the criteria for this have became. The Dutch residence-based schemes remain relatively more consistent in this respect.

\section{REFERENCES}

Beveridge, W. (1942) Social Security and Allied Services, Cmnd. 6404, London: HMSO.

Levelt-Overmars, W.M. (1988) Halen de volksverzekeringen het jaar 2000? [Do Residence-based schemes still exist in the year 2000?], Deventer: Kluwer.

Sakslin, M. (2000) 'The Concept of Residence and Social Security: Reflections on Finnish, Swedish and Community Legislation', European Journal of Migration and Law, 27(2), 157-183.

Van Der Mei, A.P. (2013) 'Overview of recent cases before the Court of Justice of the European Union', European Journal of Social Security, 15(1), 102-114.

VAn Rhijn (1945), Sociale Zekerheid, The Hague: Staatsuitgeverij.

Verschueren, H. (2007) 'De sociale bescherming van economisch niet (meer) actieve personen die zich binnen de Europese Unie verplaatsen', in VAN REGENMORTEL, A. et al. (eds.) Sociale zekerheid in het Europa van de markt en de burgers: enkele actuele thema's, Brugge: die Keure.

Verschueren, H. (2009) 'Special Non-contributory Benefits in Regulation 1408/71, Regulation 883/2004 and the Case Law of the ECJ', European Journal of Social Security, 11(1-2), 217-234.

Verschueren, H. (2014) 'Free movement or Benefit Tourism: the Unreasonable Burden of Brey?', European Journal of Migration and Law, 16(2), 147-179.

Verschueren, H. (2015a) 'Free movement of EU citizens: including for the poor?', Maastricht Journal of European and Comparative Law, 22(1), 10-34.

Verschueren, H. (2015b) 'Preventing "Benefit tourism" in the EU: A narrow or broad interpretation of the possibilities offered by the ECJ in Dano?', Common Market Law Review, 52(2) 363-390. 